\title{
A conceptual framework for teaching research in nursing
}

\author{
SCD Wright, D Tech Nursing \\ Tshwane University of Technology
}

Keywords:

teaching, research, nursing, framework

\begin{abstract}
Curationis 28(3): 4-10
Though research is often referred to the lifeblood, hallmark or cornerstone in the development of a profession (Brink, 1996:2), teaching research in Nursing is a challenge. The challenge does not just lie in teaching the subject, but in resistance and unwillingness of students to engage in the subject. In the experience of the researcher, registered nurses identify themselves with being a nurse and a caregiver; the role of researcher has never been internalised. The challenge is to achieve the outcome envisaged, namely, nurses who are knowledgeable consumers of research as well as continuous productive scholars in their application of nursing. Research generates knowledge and knowledge is the basis of caring with excellence. Nursing is an art and a science and the science must produce the knowledge upon which the art is based. The purpose of this article is to propose a conceptual framework of how to teach research in order to achieve such a successful outcome. The conceptual framework proposed in this article is based on four pillars, theoretical knowledge of research, scientific writing, psychological support and experiential learning. The importance of the research facilitator, not just as a teacher but also as a positive role model, is also described.
\end{abstract}

\section{Opsomming}

Die onderrig van navorsing in Verpleegkunde is ' $n$ uitdaging alhoewel navorsing as fundamenteel tot die ontwikkeling van "n professie beskou word (Brink, 1996:2). Die uitdaging is nie alleen geleë in die onderwerp en die onderrig daarvan nie, maar in die onwilligheid en teenstand van studente om in navorsing betrokke te raak. Geregistreerde verpleegkundiges identifiseer hulself met die rol as verpleegkundige. Die rol as navorser is nooit internaliseer nie. Die uitdaging is om die gestelde uitkoms, naamlik ' $n$ verpleegkundige wat beide ' $n$ bekwame verbruiker van navorsing en ook ' $n$ produktiewe student is, te bereik. Navorsing genereer kennis wat die grondslag van uitnemende sorg is. Verpleging is beide " $n$ kuns en 'n wetenskap en die wetenskap moet die kennis verskaf waarop die kuns baseer word. Die doel van die artikel is om ' $n$ omvattende raamwerk voor te stel om navorsing te doseer ten einde die gewensde uitkoms te bereik. Die raamwerk aangebied in die artikel word in terme van vier pilare, naamlik teoretiese kennis, wetenskaplike skryfkuns, psigologiese ondersteuning en ervaringsleer, beskryf. Die belangrikheid van die fasiliteerder, nie net as ' $n$ dosent nie maar ook as 'n positiewe rolmodel, is ook bespreek.

Teaching nursing research is challenging. The challenge does not just lie in the ability of the teacher and teaching the subject, but also in the resistance and unwillingness of students to engage in the subject (Ax \& Kincade, 2001:161). The challenge is thus to achieve the outcome envisaged, namely, nurses who are also researchers.
The term researcher is used as an umbrella term. The definition of a nurse researcher does not only include academic teaching staff or a clinical specialist in a research position of an academic hospital. Being a researcher also does not necessarily imply having all the knowledge about research or being able to publish scientific articles. There 
should rather be a researcher continuum with a starting point where nurses may lack knowledge and feel uncertain on the one side, to distinguished researchers in nursing on the other side. A comprehensive definition of a nurse researcher is thus a nurse with an inquiring mind, a nurse who is not willing to accept the status quo, and a nurse that can see patterns and ask the question: why?

Nurses should engage in research for the simple reason to gather knowledge on their subject. According to Emerson and Records (2005:9), the viability of any profession is dependent upon ongoing generation and dissemination of knowledge. Nursing is an art and a science and the science must produce the knowledge upon which the art is based. According to Searle and Pera (1992:404), the credibility of nursing lies in the value and quality of its service to people, which requires a sound knowledge base. Unfortunately, knowledge in nursing is often based on tradition, authority, borrowing, trial and error and personal experience (Burns \& Grove, 1997:12). The scope of the problem is delineated by Kaunda and Low (1998:135) who writes that none or very little clinical research is done outside the realm of academia and that clinical studies generated by registered nurses are nonexistent. The authors ascribe part of the underlying problem to the way students are educated.

Observing registered nurses' attitude towards research from a particular perspective, the experience of fourth-year $B$ Tech Nursing students of Technikon Pretoria in 2003, is worth reporting. As part of their nursing research module, the students are required to write a protocol in the first semester. The topic of the research is pre-determined, as the protocol and the implementation of the protocol are experiential learning activities. In 2003, the topic was to determine the knowledge and attitude of registered nurses in a clinical setting regarding nursing research. Each student prepared his/her own protocol, and after approval, conducted the research in the specific clinical setting that he/she was working. The students were all working in one of nine private high care or intensive care units. Of all the personnel in the nine units, only 16 registered nurses were willing to complete a questionnaire. In some units, only one

Figure 1: A conceptual framework to teach research in Nursing

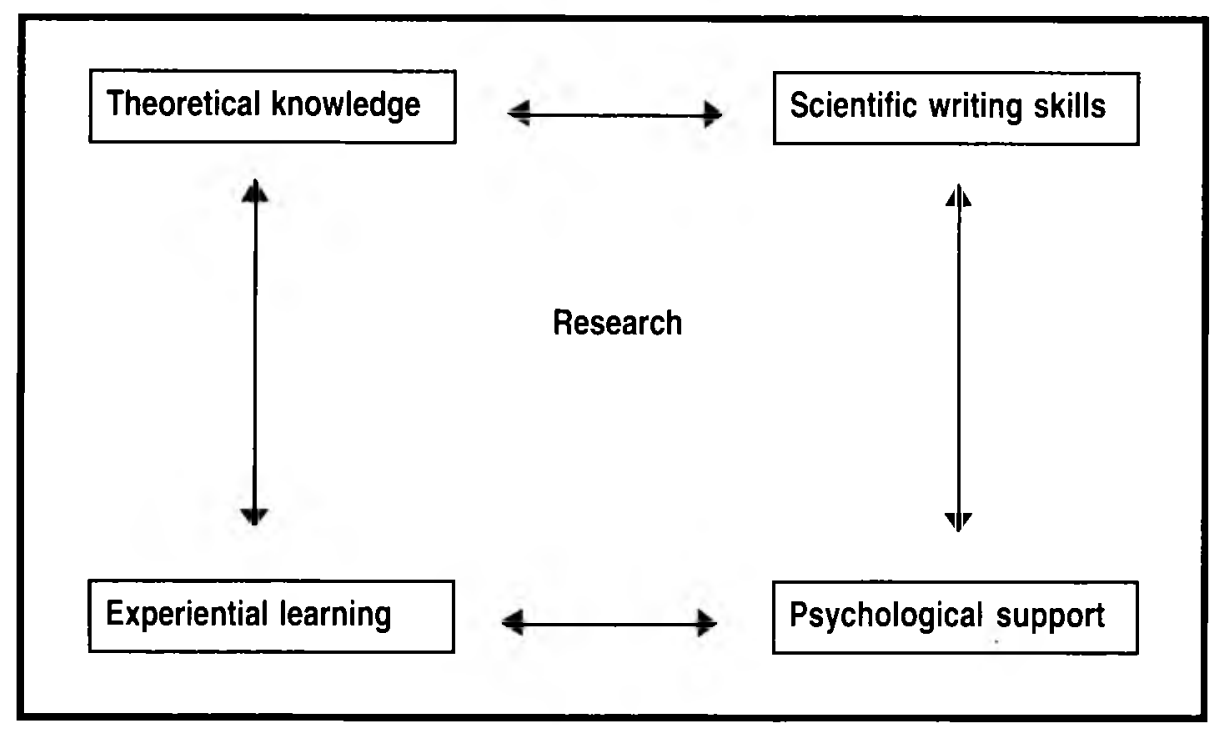

registered nurse was willing to complete a questionnaire. The refusal to consent was a direct result of reading the informed consent letter, which indicated that their participation was to determine basic research knowledge. The results of the 16 completed questionnaires revealed a serious lack of basic research knowledge.

One of the reasons why nursing students find research so challenging may be the understanding of the South African Nursing Council's definition of nursing:

"Nursing science is a human clinical health science that constitutes the body of knowledge for the practice of persons, registered or enrolled under the Nursing Act as nurses or midwifes. Within the parameters of nursing philosophy and ethics it is concerned with the development of knowledge (my accentuation) for the nursing diagnosis, treatment and personalised health care of persons exposed to, suffering, or recovering from physical or mental illhealth. It encompasses the knowledge of preventative, promotive, curative and rehabilitative health care for individuals, groups and communities and covers man's life span from before birth" (Searle \& Pera, 1992:156).

This definition of nursing incorporates the basic elements of most other definitions of nursing and is a comprehensive statement of what nursing is. My premise is that nurses, students or registered, only focus on a few aspects of the definition such as clinical health. nursing diagnosis, treatment. health care and individuals, groups and communities. The focus is on people with a health-related problem that they can assist and care for in some way, be it preventative, promotive, curative or rehabilitative. While thinking is part of this process. it is demarcated by the lines of doing a specific intervention. Registered nurses, who have been in their specific fields of nursing for some time, hardly 'think' at all outside those lines. They are masters of their discipline and can diagnose a problem and prescribe a nursing intervention without consciously going through the systematic decision-making process. They are knowledgeable in their field of expertise and comfortable in their role as a nurse. In fact, they are safe practitioners of the art and science of nursing.

Knowledge has its place in this whole process; knowledge is needed to be able to fulfil this role safely and efficiently. Knowledge is a prerequisite to registration, but registration is only an arrival. Registration is the purpose most students work so hard to achieve. After registration, the focus is honing the learned skills in the registered nurse's chosen speciality. For most registered nurses, this is what nursing is about and there is nothing wrong with the concept. The only problem is the definition of nursing.

The definition embraces another equally important concept, namely the 'development of knowledge'. Registered nurses are charged with not only using existing knowledge. but also to develop new knowledge and the method for doing so, is research. The definition does not stipulate a specific category of nurse to 
do research; knowledge has to be developed by all nurses. Research needs not always be a random clinical trail and nurses should not perceive research as something that is done only as an individual or as an activity apart from her normal day-to-day work.

The question is: how should research be taught to have the desired outcome of nurses who are knowledgeable consumers of research as well as continuous productive scholars in their application of nursing? The purpose of this article is to propose a conceptual framework (Figure 1) of how to teach research in order to achieve such a successful outcome. The conceptual framework is based on four pillars, theoretical knowledge of research, scientific writing, psychological support and experiential learning. This framework has been developed and tested during the past four years while teaching research to undergraduate and postgraduate nursing students at Tshwane University of Technology (previously Technikon Pretoria).

\section{Developing a conceptual framework to teach nursing research \\ Participants}

There were two distinct groups of nursing students at Tshwane University of Technology who are varied in their composition and their previous exposure to research. According to Reg. 2598 (South African Nursing Council, 1984), research is a compulsory component of the training and education of nursing students. The groups differ in the followings aspects:

Group 1:

The first group is B. Tech Nursing undergraduate students for first registration as a registered nurse and midwife. These students are postsecondary school and have no previous exposure to nursing or research.

Group 2:

The second group is postgraduate students who are registered nurses, advancing their careers by obtaining additional qualifications. These qualifications are also on the baccalaureate level and the research module is a core module in the elective programme for which they are registered. The elective programme may be, for example, oncology nursing or

\section{Figure 2: Students' feelings after their first attempt to write a research proposal}

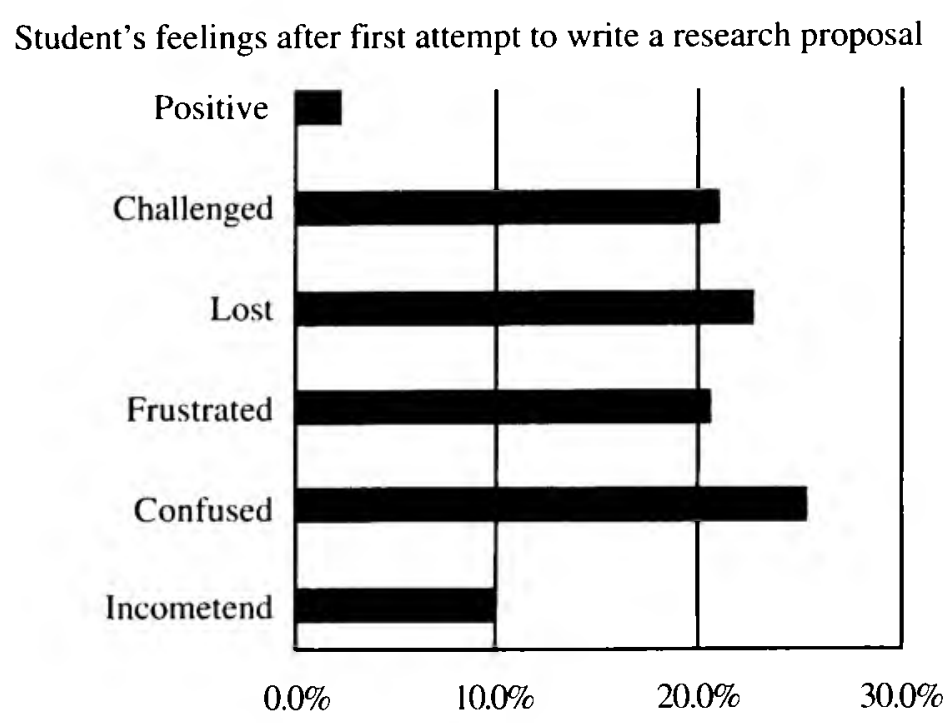

occupational health nursing. The composition of this group is quite variable. Some students are from rural areas working in the primary health care environment while others are working in intensive care units in urban areas. Their nursing experience is vastly different. Some completed their basic training thirty years ago while other qualified recently. Their ages vary from late twenties to late fifties. Some of the students are unit managers while others are still on a junior level. However, there are two attributes present in all members of the group. Firstly, they are all registered nurses, and secondly, they all had previous exposure to a taught research module.

These students were asked, during the first contact session, to quantify their ability and willingness to do research using a Visual Analogue scale (Scale: from $0-10$, where $0=$ not able or not willing and $10=$ able and willing). The results for 2003 were as follows: for the evaluation of their own ability, the mean was three (range $0-7$ ) and for their willingness, the mean was 7.5 (range 2 10). These results are in line with the results of previous groups in 2000 to 2002 (Zeelie, 2002:182). None of the students engaged in an own research project since registration. Previous exposure to research did not empower these students to write a research proposal, implement research or publish the results.

However, this group of students is very important to nursing. These registered nurses are future oriented and are advancing their careers with an additional qualification. They are careeroriented registered nurses who are prepared to study part-time. They are the future leaders of nursing in South Africa.

\section{Theoretical knowledge}

Theoretical knowledge is the foundation of any discipline. What must be considered though is how much of the vast body of research knowledge a baccalaureate student should have to cope with. Undergraduate students should be taught enough research theory to assist them to use their textbooks intelligently, because research is an open book discipline. There is no need to memorise theory. Students should be able to apply the principles in drafting an accountable proposal, implementing the research and writing a scientific report. Application and synthesis is the cognitive levels required of the student, not memorising.

To facilitate the students' exploration of the theoretical basis of research, a structured approach has been developed. The approach is an 11-decision proposal development guide (Table 1), and it is the basis of a core lecture at the beginning of the year. The guide provides a synopsis of the choices the student could take and is not meant to be exhaustive. The most common research decisions taken in a first attempt at writing a proposal is provided. A working knowledge of this guide is important. The students must understand the theoretical 
Table 1: The 11-decision proposal development guide

\begin{tabular}{|c|c|c|}
\hline Decision & Research component & Criteria/possible choices \\
\hline 1 & Research problem & Criteria: population, context and variables \\
\hline 2 & Purpose and aims & Criteria: population, context and variables \\
\hline 3 & Theoretical basis of study & $\begin{array}{l}\text { Choice of theory, framework, process or approach as basis of the } \\
\text { study }\end{array}$ \\
\hline 4 & Strategy & $\begin{array}{l}\text { Exploratory } \\
\text { Descriptive } \\
\text { Explanatory }\end{array}$ \\
\hline 5 & Context & $\begin{array}{l}\text { Contextual } \\
\text { Universal }\end{array}$ \\
\hline 6 & Research design & $\begin{array}{l}\text { Quantitative and most often used designs } \\
\text { Qualitative and most often used designs }\end{array}$ \\
\hline 7 & Population & 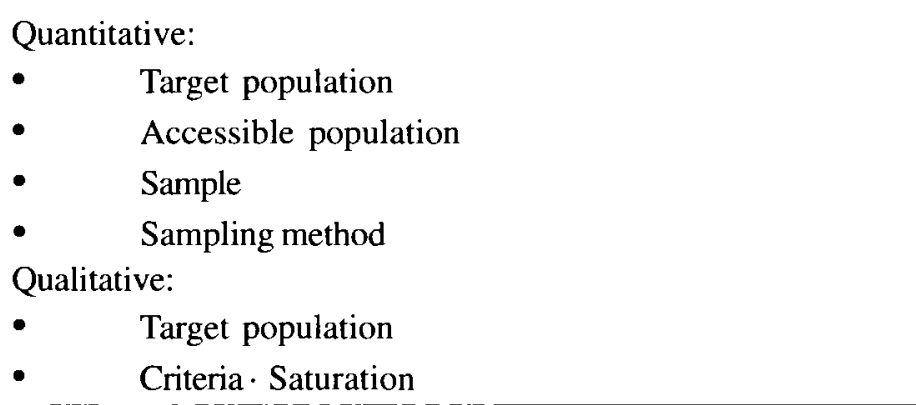 \\
\hline 8 & Data gathering & $\begin{array}{l}\text { Self-report } \\
\text { Observation } \\
\text { Measurement } \\
\text { Critical incident } \\
\text { Vignettes } \\
\text { Reports }\end{array}$ \\
\hline 9 & Data analysis & $\begin{array}{l}\text { Numerical: descriptive and statistical } \\
\text { Verbal: open and thematic coding }\end{array}$ \\
\hline 10 & Reliability and validity / trustworthiness & $\begin{array}{l}\text { Quantitative: validity and reliability } \\
\text { Qualitative: trustworthiness }\end{array}$ \\
\hline 11 & Concepts & Variables of the study \\
\hline
\end{tabular}

basis of the research process and the required coherence of the choices they make. For example, should a student choose a qualitative design, none of the random sampling methods would be applicable. Guided by the framework, the students learn to use research textbooks as a resource. Students use the 11 decision guide for the initial draft of the proposal, pencil, paper, and two landscape A4 sheets of paper, cellotaped it in the middle with 11 columns drawn on the paper. These columns are headed by the titles of the 11 decisions. In the first column, the student writes the research problem and takes the rest of the decisions that will solve the research problem. The student may only start to write the proposal after all the decisions taken are correct in terms of the research problem.

The advantage of this framework is that the research process is reduced to manageable pieces of information that are user-friendly. Once students have some experience, for example, when they have to develop their own proposal, they are able to take coherent decisions for their research problems. Another advantage is that the theoretical basis of the proposal is approved before the student starts writing and because the student knows that his/her decisions are approved, writing the proposal is less frustrating. The focus can then shift to the quality of the scientific writing.

The bridge from the 11-decisions to the proposal is presented in Table 2. All the decisions are incorporated in the proposal. As can be seen from the table, 
Table 2: Using the 11-decision framework as the basis of the research proposal

\begin{tabular}{|c|c|c|}
\hline Decision & $\begin{array}{l}\text { Contents } \\
\text { number }\end{array}$ & Application in proposal \\
\hline & 1 & Background and rationale \\
\hline 1: Research problem & 2 & Research problem and sub problems if applicable \\
\hline 2: Purpose and aims & 3 & Purpose and aims if applicable \\
\hline \multirow[t]{5}{*}{ 3: Theoretical basis of study } & 4 & Theoretical basis of study \\
\hline & 4.1 & Theory, framework, process or approach chosen \\
\hline & 4.2 & Hypothesis/central theoretical statement \\
\hline & 4.3 & Definitions \\
\hline & $5 \cdot$ & Research methods and design \\
\hline 4: Strategy & 5.1 & Strategy \\
\hline 5: Context & 5.2 & Context \\
\hline 6: Research design & 5.3 & Design \\
\hline 7: Population & 6 & Population \\
\hline 8: Data gathering & 7 & Data gathering \\
\hline 9: Data analysis & 8 & Data analysis \\
\hline \multirow{3}{*}{$\begin{array}{l}\text { 10: Reliability and validity / } \\
\text { trustworthiness }\end{array}$} & 9 & Reliability and validity / trustworthiness \\
\hline & & \\
\hline & 10 & Ethical considerations \\
\hline 11: Concepts & & \\
\hline
\end{tabular}

no decision is taken about the ethical considerations in the proposal. The ethical considerations are part of the proposal. The content number and application in the proposal columns becomes the contents/index page of the proposal. This provides a structured approach and it facilitates the development of the proposal on the baccalaureate level.

Decision 11, the CONCEPTS of the study, is foundational in assisting the student to write the proposal. The reason for having decision 11 is evident at this point. This last decision becomes the departure point for the proposal. The concepts or variables of the study serve as keywords for the literature search for the background of the proposal. From experience, it is clear that students find it difficult to write a suitable background. Having the students focus on the concepts again provides a structured approach. The students are taught to arrange the concepts from the most important concept for the study and build a logical argument in the background around these concepts. At this point, the students know what to write and how to organise their writing. How to do the writing is the next obstacle for them to overcome.

\section{Scientific writing}

Writing is something nurses do everyday, because it is part of nursing. Nurses report on their activities and their observations of the patient's health problems and his/her reaction to therapy in writing. The style of writing is of a direct nature, directly stating an observed problem or action taken. The sentences are often short and incomplete.

However, writing a paragraph of 300 words in the postgraduate research module is a completely different challenge. Students are asked to write a paragraph of 300 words on an innocuous subject such as water or chocolate or a milkshake. To emphasise the lack of writing skills, most of students from a class of 35 - 40 are unable to complete such a learning activity. Writing in a narrative style is a skill that has to be developed. Another factor that influence the students' writing ability is that most students are writing in a second language - English, and their freedom of expression is thus limited.

To address the problem, the following aspects should be considered. Instruction in scientific writing should be guided by a pre-planned curriculum. Specific objectives must be developed and the learning activities to achieve the objectives must be planned. Develop assessment criteria that clearly indicate to the student the expected standard. Accept that the students do not have any scientific writing skills and develop learning activities that will develop the skills to an acceptable level. According to Pimple (2002: no page number), frequent writing assignments, regardless of content, dramatically improve writing skills. Asking students to think "on paper" about topics encourages them to 
think about those topics in greater depth. At Tshwane University of Technology both undergraduate and postgraduate students, the objective for the research module is to develop a research proposal on a theme of their own choice. Proposal writing demands a high level of scientific writing competence.

Students should also be taught how to organise a complex document such as a research proposal. Not just the macro organisation of the various components of the proposal for example the background and justification, research problem and research design and methods but also the micro organisation of the paper. The following aspects are important: writing of a paragraph, linking of paragraphs, organisation of a complex argument, writing concisely, proving their assertions, and revision of the final draft. Clear, succinct writing is a valuable asset for any researcher. Students also struggle with citations and the references in their proposals. Guidance early in the year saves many revisions for both the facilitator and the student.

Using the 11-decision proposal development framework as the backbone of the proposal facilitates the student's progression towards a proposal that is theoretically well founded. The students need a structured approach on the baccalaureate level, which may be abandoned at the masters or doctorate level. At the baccalaureate level, the students do not yet have the necessary self-confidence to develop a research proposal from scratch. A structured approach also makes the students feel secure and at least, in charge to some extent.

\section{Psychological support}

Psychological support is the most crucial of the four pillars. Students may have theoretical knowledge and be able to write a scientific paper, but if their feelings of insecurity are not addressed, their attitude towards research will not change. Students feel confused and insecure even though they have been guided through the process of what and how to write. To be able to understand the level of confusion and incompetence students are experiencing when they are writing a research proposal the first time, the sequence of learning experiences in the research module must be described.

As was explained earlier, the students are required to write a group proposal in the first semester and they are guided through the process by using the 11 decision proposal development framework. Before they attempt their first proposal, the following instruction has already taken place:

- All the decisions, upon which the proposal is based, are taken in class; thus, the students know exactly what they have to write in each section of the proposal.

- $\quad$ They are facilitated in the macro organisation of the proposal by being given the index to follow throughout the document.

- $\quad$ They are guided through the principles of paragraph writing and linking paragraphs together.

- In their learner guides, there are examples on how to write specific sections of the proposal and they are guided through the citation requirements for the proposal.

All the students have to do is write the proposal. It almost seems too easy, but the disquiet in the class the following contact session contradicts the statement. Figure 2 illustrates the students' $(n=30)$ feelings after writing that first proposal. The most common feeling is being confused $(24.5 \%)$. Students reported feelings such as being unsure, bewildered and hopeless. The second most common feeling is a feeling of being lost $(22.4 \%)$. Feeling frustrated (20.4\%) was also reported frequently. Feeling hysterical, angry, regret at having entered the programme, irritated and stuck was clustered in the frustrated category. The student, who reported being angry, said it with so much emotion it there can be no doubt about how she felt. Students also felt challenged (20.4\%) and incompetent $(10.2 \%)$. Only $2 \%$ of the students felt positive. The words the students used to convey their feelings clearly indicate negative emotions. Take in consideration that these registered nurses are used to feeling very confident in their nursing roles.

If these feelings of frustration, confusion, being lost and incompetent are not dealt with, there is no chance that the students will complete the programme and do research in their clinical work or go on to do a masters degree. Psychological support is of the utmost importance to assist students to progress to being confident and in control again.

To support the students psychologically, the following aspects could be considered:

- $\quad$ Acknowledge the negative feelings. Recognising that the feelings exist and are part of a 'normal' reaction of students at this stage of the programme goes a long way in defusing the situation. Explain to the students that they are busy with a different subject and that they are learning a different set of knowledge and skills and at this stage, are still inexperienced. Experience is a result of doing repeatedly; it is not a result of never making a mistake. If the students do not open and go through this door, they are lost to research. In addition, if these feelings are discussed openly, the students understand that they are not alone in their predicament. From the experience of the last four years, the students do progress from this stage and most complete the programme quite positively.

- Emphasise the importance of the research role of nurses, because students have never internalised this role. Confer importance on research and specifically the role that they personally have to play in contributing to the health of all in South Africa.

- $\quad$ Have an open door policy. The students must never feel that they are without immediate recourse to assistance. Give them your cell phone number and invite them to use it at any time.

- $\quad$ Be a role model; be a researcher. Do not preach research if you do not do so yourself. Let your students read your articles in refereed journals. Use your own questionnaires as examples for the students or use a transcription of a qualitative interview you have done to give them experience in open coding. Be enthusiastic about research. Read research and devour research textbooks so 
that you have an answer most times when you are asked a question.

\section{Experiential learning}

The fourth pillar of the framework is experiential learning. Without doing research and becoming experienced to some extent before they complete the module, students will still not overcome their negativity regarding research. The students have to accomplish the specific outcomes of the module. In terms of the research module, this means a number of doing assignments, for example:

\section{- Enhancement of scientific writing assignments \\ - Development of a questionnaire \\ - $\quad$ Analysing quantitative and qualitative data \\ - Writing letters of consent \\ - Writing the group proposal that is implemented, the data analysed and a scientific report written. \\ - Writing of an abstract \\ - Drafting a proposal of the student's own choice. \\ - $\quad$ Presenting the proposal and evaluating co-students' proposals. \\ At the time of writing their own proposal, the students have some experience in doing so and as a rule, they enter into this phase quite positively. \\ Role of the research facilitator in the conceptual framework}

The role of the facilitator is varied. One has to be a knowledgeable researcher, a published author, a psychological supporter and most importantly, a research role model. As the educational philosophy of the department is selfdirected learning, the students are responsible for their own learning. Using the framework, a core lecture is presented during the first contact session of the year. Thereafter, specific elements of the research process will be dealt with in more depth, for example, sampling methods or data analysis. As the focus is not only on theoretical knowledge, the role of the facilitator is to guide the students through achieving the specific objectives of the module.

\section{Conclusion}

Teaching research in nursing is challenging. If the facilitator is inexperienced and insecure, it is an intimidating task without much hope of success. The facilitator will hide behind theoretical knowledge and unconsciously create a distance between her/him and research. Success is directly correlated with the degree the facilitator has internalised research her/himself.

The following aspects are of importance:

- $\quad$ The four pillars of the conceptual framework are of equal importance. If one is left out, failure is inevitable. If students do not have knowledge, or if they cannot write scientifically or if they are not supported psychologically or if they only have a theoretical course, they will remain negative about research.

- There are no research role model in the clinical setting. The only role model for students is the facilitator. Even if the students do become positive about research, when they are in their clinical setting, research is a foreign concept to most registered nurses.

- $\quad$ Registered nurses have no sense of a researcher role - the role of researcher should be marketed aggressively.

- $\quad$ Registered nurses furthering their careers are most prone to uncertainty. Their previous exposure to a research course has not empowered them to do research and their feelings of incompetence must be addressed for them to progress on the researcher continuum. As was shown, the students are willing to engage in research, but do not feel competent.

- $\quad$ Acknowledge feelings of confusion and incompetence. The role of the facilitator in this regard is crucial and if addressed correctly, the students progress through this phase to a more positive attitude regarding research.

- Using the proposed framework as basis, plan specific outcomes of the module accordingly. With good planning, even if the facilitator is still inexperienced, success in teaching research could be achieved.

\section{References}

AX, S \& KINKADE, E 2001: Nursing students' perceptions of research: usefulness, implementation and training. Journal of Advanced Nursing. 35(2):161170.

BURNS, N \& GROVE, SK 1997: The practice of nursing research conduct: critique \& utilization. Philadelphia: WB Saunders.

EMERSON, RJ \& RECORDS, K 2004: Nursing: Profession in Peril. Journal of Professional Nursing. 21(1):9-15.

KAUNDA, L \& LOW, T 1998: Growing our own timber. students and supervisors' perceptions of research at honours level at the University of Cape Town. South African Journal for Higher Education. 12(3): 130-139.

PIMPLE, K 2002: Using Short Writing Assignments in Teaching Research Ethics. [Online]. Avaiable at: < http:// poynter.indiana.edu/tre-wrtg.html>. Accessed: 28/05/2003

SEARLE, C \& PERA, S 1992: Professional practice: a South African nursing perspective. 2nd ed. Durban: Butterworths.

\section{SOUTH AFRICAN NURSING} COUNCIL 1984: Reg. 2598 of November 1984, as amended. Regulation regarding the scope of practice of persons registered or enrolled in terms of the Nursing Act of 1978. Pretoria: Government Printer.

ZEELIE, SCD 2002: A self-evaluation system for quality assurance in nursing research. D. Tech dissertation, Technikon Pretoria. Unpublished. 